\title{
Diabetic ketoacidosis precipitated by COVID-19 in patient with newly diagnosed diabetes mellitus
}

For citation: Mižnarodnij endokrinologičnij žurnal. 2021;17(5):422-425. doi: 10.22141/2224-0721.17.5.2021.241521

\begin{abstract}
Background. Coronavirus disease 2019 (COVID-19) is a viral infectious disease caused by severe acute respiratory syndrome coronavirus 2 (SARS-CoV-2). Diabetes mellitus (DM) have been reported frequently in patients with the new corona virus disease -2019, COVID-19. It has been associated with progressive course and worse outcome. There is scarce data on diabetic ketoacidosis (DKA) in COVID-19 infection. There has been several cases reported on COVID-19 infection precipitating a new diagnosis of type 2 DM (T2DM). However, there is a lack of evidence regarding type 1 DM (T1DM). We report a case of DKA precipitated by COVID-19 in a patient with newly diagnosed T1DM. Recently, case reports and small cross-sectional studies described diabetic patients who develop DKA when infected with COVID-19. The incidence of DKA has been found to be high in patients with T1DM and T2DM admitted to hospital with COVID-19. Case presentation. We present a 29 year-old, previously healthy man with 5 days history of fever, fatigue, vomiting, polydipsia and polyuria. His lab results showed high blood glucose, high anion gap metabolic acidosis and ketonuria diagnostic of DKA. He also tested positive for COVID-19 and his Chest CT was consistent with bilateral COVID 19 pneumonia (ground-glass opacity, consolidation, and crazy-paving pattern). He was successfully managed with intravenous fluids and insulin as per DKA protocol. He required intravenous antibiotics, steroids and oxygenotherapy for COVID-19 pneumonia. He was discharged after 14 days in stable condition. Conclusions. COVID-19 infection can be complicated by DKA and development of DM in previously non-diabetic individuals. It is possible that SARS-CoV-2 may aggravate pancreatic beta cell function and precipitate DKA. Very few cases have been reported in the literature on COVID-19 infection precipitating DKA in a newly diagnosed patient of type 1 diabetes mellitus.
\end{abstract}

Keywords: type 1 diabetes; diabetic ketoacidosis; COVID-19 pneumonia

\section{Introduction}

The Coronavirus Disease 19 (COVID-19) is an infectious disease caused by a novel coronavirus, the Severe Acute Respiratory Syndrome Coronavirus 2 (SARS-CoV-2) [1].

During COVID-19 pandemic, diabetes mellitus (DM) was found to be a risk factor for severe disease and worse outcomes [2]. A history of DM was associated with $22.5 \%$ of COVID-19 intensive care unit admissions in one case series [3] and a mortality rate up to $16 \%$ among people with DM and without other comorbidities [4, 5].

The development of diabetic ketoacidosis (DKA) can in itself add to this high mortality in COVID-19 patients.

Several studies have demonstrated that COVID-19 can utilize angiotensin-converting enzyme 2 (ACE2) on the surfaces of epithelial cells to bind and gain entry to infected cells [6]. Similar findings were reported during SARS outbreak in 2006 [7]. Binding of ACE2 by SARS-CoV-2 in
COVID-19 may play an important role in the pathogenesis of the disease on one hand and could predispose patients to hyperglycemia and development of DM on the other hand. Herein, we describe a patient who was previously healthy, but presented with DKA and new onset of DM complicating COVID-19 pneumonia.

\section{Case presentation}

A 29-years old previously healthy man, who was not known to have DM but presented to the emergency department (ED) with fatigue and decrease in activity for 5 days along with generalized body aches and nocturia (about 67 times/night). On admission, his temperature was $38.8^{\circ} \mathrm{C}$. He was hemodynamically stable but mildly tachypneic. He did not require supplemental oxygen during the first hours of admission in hospital. He denied any respiratory symptoms or chest pain. He had 3 days history of fever, tiredness and loss of smell and taste. 
Given positive contact history, he was tested and confirmed to be infected with severe acute respiratory syndrome coronavirus 2 (SARS-CoV-2).

$\mathrm{He}$ is non-smoker and has no family history of DM.

Upon examination in the emergency room, he was conscious and oriented to time, place and person but looked dehydrated. He was febrile, but he did not display Kussmaul's breathing. His respiratory rate was fluctuating $22-26 / \mathrm{min}$, and $\mathrm{O}_{2}$ saturation was $96 \%$ without $\mathrm{O}_{2}$ therapy. His body mass index was $21.6 \mathrm{~kg} / \mathrm{m}^{2}$ with no signs of insulin resistance.

Laboratory investigations were significant for hyperglycaemia $479 \mathrm{mg} / \mathrm{dl}$, high anion gap $26 \mathrm{mEq} / \mathrm{L}$, metabolic acidosis: Base excess $=-23.2 \mathrm{mEq} / \mathrm{L} ; \mathrm{pH} 7.140$ and ketonuria $+3(150 \mathrm{md} / \mathrm{dl})$, confirming the diagnosis of DKA.

The rest of his investigations showed the following:

- BUN: $51 \mathrm{mg} / \mathrm{dl}$, normal range (10-50).

- Creatinine: $1.2 \mathrm{mg} / \mathrm{dl}$, normal range $(<1,3)$.

$-\mathrm{SGPT}=20 \mathrm{U} / 1$, normal range $(0-46)$.

- Na: $129 \mathrm{mmol} / \mathrm{l}$, normal range (135-145).

- K: $2.9 \mathrm{mmol} / \mathrm{l}$, normal range (3.5-5.1).

- Cl: $95 \mathrm{mmol} / \mathrm{l}$, normal range (98-107).

- S. lactate: $1.4 \mathrm{mmol} / 1$ normal range $(0.5-1.1)$.

- WBC: $11.05 \times 10^{\wedge} 3 / 1$, normal range (4-11).

- Lymphocytes: $12.1 \%$; normal range (25-40 \%).

- Hgb: $14.1 \mathrm{gm} / 1$, normal range (12-14).

- Platelets: $281 \times 10^{\wedge} 3 / 1$, normal range (140-400).

- Chest X-ray: showed bilateral infiltration.

- Chest CT: CO-RADS category 5; bilateral groundglass opacities and crazy-paving pattern, $70 \%$ involment of the lungs, CT severity score $=18 / 25$.

- Insulin $2.74 \mu \mathrm{IU} / 1$, normal range $(2.6-24.9 \mu \mathrm{IU} / 1)$.

- C-peptide 0.856 (ng/ml), normal range (0.8$3.1 \mathrm{ng} / \mathrm{ml}$ ).

- Anti GAD-IgG - Negative $<5(<10$ Negative $;>10$ Positive).

- HbA1c: $12.8 \%$.

Oronasal swab was positive for COVID-19 by real-time reverse transcription-polymerase chain reaction (rRT-PCR) test.

Urinalysis revealed $1000 \mathrm{mg} / \mathrm{dl}$ of glucose, $150 \mathrm{mg} / \mathrm{dl}$ of ketones and $30 \mathrm{mg} / \mathrm{dl}$ of protein.

Inflammatory markers:

- CRP: $25.23 \mathrm{md} / \mathrm{dl}$, normal range $(<10 \mathrm{mg} / 1 \mathrm{Nega}-$ tive; > $10 \mathrm{mg} / 1$ Positive).

- LDH: 792 unit/1, normal range (210-450).

- Ferritin: $1842 \mathrm{mg} / \mathrm{dl}$; normal range (20-400).

- D dimer: $1969 \mathrm{mg} / \mathrm{dl}$, normal range $(0-500)$.

Cardiac evaluation:

- ECG normal sinus rhythm.

- Cardiac enzymes and troponin were normal.

In ED, he received 14 units IV regular insulin as a bolus and 1 litres of IV normal saline and started on DKA protocol with insulin infusion, IV fluids and potassium replacements. Serum electrolytes were closely monitored. DKA resolved after $24 \mathrm{hrs}$ and he was transitioned to subcutaneous insulin therapy. He stayed in the hospital for 14 days and completed ten days course of antibiotics, Levofloxacin $500 \mathrm{mg}$ and Meropenem $3 \mathrm{~g}$. The day after admission he was assisted with oxygen therapy because her saturations fall to $86 \%$.
He was managed with 20 litres high flow oxygen and 5 days course of dexamethason $4 \mathrm{mg}$, two times daily with a gradual decrease of doses. Fourteen days later he was weaned off Oxygen and he was discharged on insulin Aspart 6 UI before each meal and insulin Lantus 14 UI once daily. $\mathrm{He}$ was recommended to contact his local endocrinologist after four weeks, for the follow up consult.

\section{Discussion}

The patient in this case report was presented with two life threatening conditions, DKA and COVID-19 pneumonia. The prompt recognition and treatment of these conditions is crucial and resulted in good outcome.

DKA is a diabetic emergency and considered to be a common presentation of both T1DM and T2DM. It arise as a result of severe insulin deficiency, increased counter regulatory response which results in the production of ketones [8].

The most common trigger factors are prolonged uncontrolled blood sugar or acute stress including infection (pneumonia, urinary tract infection), acute myocardial infarction or cerebrovascular accident. Also alcohol abuse and drugs like SGLT-2 inhibitors [9] can precipitate an DKA episode.

The patient in this case report was presented with DKA and newly diagnosed T1DM triggered by COVID-19 pneumonia.

The underlying pathophysiology of new onset DM and its severe form DKA in patients with COVID-19 is still not well understood. Viral infection have been widely associated with T1DM pathogenesis.

T1DM is a genetic autoimmune condition where b-cells are destroyed by the auto-reactive CD4p and CD8p T cells causing insulin deficiency [10].

The severe acute respiratory syndrome-coronavirus-2 (SARS-CoV-2), responsible for COVID-19, uses ACE2 receptor to bind and enter to infected cells as a viral complex [6].

Angiotensin converting enzyme (ACE) is the key enzyme in mediating the effects of rennin angiotensin aldosterone system (RAAS) by converting angiotensin I to II. The more recently identified to angiotensin I-VII, was found to be the functional receptor for SARS-CoV-1 and -2 [11].

ACE2 is abundantly present in humans in the epithelia of the lung and small intestine, which might provide possible routes of entry for the SARS-CoV-1 and -2 [12]. Study of 72 human tissues confirmed ACE2 mRNA expression in tissues other than the lung and gastrointestinal system, like testis, cardiovascular, renal, and pancreas [13, 14].

It was found that ACE2 is expressed in the endocrine part of the pancreas. This suggests that SARS coronavirus enters islets cells using ACE2 as its receptor and damages $\mathrm{B}$-cell islets leading to insulin deficiency and development of acute DM [7].

This is supported by the findings of strong immunopositivity for ACE2 in pancreatic islets while exocrine tissues were only weakly positive [15]. Similarly, evidence in diabetic mice demonstrated that ACE2 activity levels were enhanced in the pancreas $[15,16]$.

In addition to the direct $\mathrm{B}$ cell injury, the expression of ACE2 on the surface of the pancreas is downregulated fol- 
lowing endocytosis of the virus-ACE2 receptor complex. This in turn can lead to increase concentration of angiotensin II and inhibit insulin secretion [17]. These interactions between SARS-CoV-2 and RAAS might explain the underlying mechanism and pathophysiology of DKA.

All these pathophysiological events occurring simultaneously with inflammatory stress because of pulmonary infection might have contributed to the acute worsening of pancreatic beta cell function and precipitated DKA in this patient.

It remains to be investigated, whether this beta cell damage is transient or permanent.

Our understanding so far is uncertain if this new-onset diabetes is classic T1DM or some new form of DM.

The presentation of the patient in this case report is consistent with the hypothesis that COVID-19, not only causes hyperglycaemia and insulin resistance in patients known to be diabetic $[3,18]$, but can also predisposes newly diagnosed diabetes mellitus to DKA which can sometimes be resistant to treatment [19-21].

The development of diabetes and DKA can further complicate the course of COVID-19 infection. Diabetic patients with COVID-19 have worse prognosis than nondiabetics [1, 3].

This could be explained in part by high inflammatory and pro-coagulant state in diabetics including IL-6, C-reactive protein, serum ferritin, coagulation index, and D-dimer $[2,4,22]$.

While hyperglycemia is seen to increase mortality and morbidity related to COVID-19, the virus itself can induce/ worsen hyperglycemia, culminating in a vicious cycle [23].

\section{Conclusions}

There are enough evidences to conclude that COVID-19 can lead to uncontrolled hyperglycaemia and the development of new onset diabetes mellitus which can further complicate the course and outcome of COVID-19 infection.

It is possible that SARS-CoV-2 may aggravate pancreatic beta cell function and precipitate diabetic ketoacidosis in patients with known or not known diabetes.

Patients with elevated blood sugar and no history of diabetes should be evaluated for the possibility of new onset diabetes mellitus and diabetic ketoacidosis, especially in the setting of concomitant COVID-19 infection.

Further studies and long term follow-up of children and adults presenting with new-onset diabetes during this pandemic is required to fully understand the type of diabetes induced by COVID-19 and to reveal the exact underlying pathophysiological mechanism of this serious condition.

\section{References}

1. Peeri NC, Shrestha N, Rahman MS, et al. The SARS, MERS and novel coronavirus (COVID-19) epidemics, the newest and biggest global health threats: what lessons have we learned? Int J Epidemiol. 2020 Jun 1;49(3):717-726. doi: 10.1093/ije/dyaa033.

2. Huang I, Lim MA, Pranata R. Diabetes mellitus is associated with increased mortality and severity of disease in COVID-19 pneumonia - A systematic review, meta-analysis, and meta-regression. Diabetes Metab Syndr. 2020 Jul-Aug;14(4):395-403. doi: 10.1016/j.dsx.2020.04.018.
3. Wang D, Hu B, Hu C, et al. Clinical Characteristics of 138 Hospitalized Patients With 2019 Novel Coronavirus-Infected Pneumonia in Wuhan, China. JAMA. 2020 Mar 17;323(11):1061-1069. doi: 10.1001/jama.2020.1585.

4. Guo W, Li M, Dong Y, Zhou H, et al. Diabetes is a riskfactor for the progression and prognosis of COVID-19. Diabetes Metab Res Rev. 2020 Mar 31:e3319. doi: 10.1002/dmrr.3319.

5. Goldman N, Fink D, Cai J, Lee YN, Davies Z. High prevalence of COVID-19-associated diabetic ketoacidosis in UK secondary care. Diabetes Res Clin Pract. 2020 Aug;166:108291. doi: 10.1016/j.diabres.2020.108291.

6. Hoffmann M, Kleine-Weber $H$, Schroeder $S$, et al. SARS-CoV-2 Cell Entry Depends on ACE2 and TMPRSS2 and Is Blocked by a Clinically Proven Protease Inhibitor. Cell. 2020 Apr 16;181(2):271-280.e8. doi: 10.1016/j.cell.2020.02.052.

7. Yang JK, Lin SS, Ji XJ, Guo LM. Binding of SARS coronavirus to its receptor damages islets and causes acute diabetes. Acta Diabetol. 2010 Sep;47(3):193-9. doi: 10.1007/s00592-009-01094.

8. Umpierrez G, Korytkowski M. Diabetic emergencies - ketoacidosis, hyperglycaemic hyperosmolar state and hypoglycaemia. Nat Rev Endocrinol. 2016 Apr;12(4):222-32. doi: 10.1038/nrendo.2016.15.

9. Rosenstock J, Ferrannini E. Euglycemic Diabetic Ketoacidosis: A Predictable, Detectable, and Preventable Safety Concern With SGLT2 Inhibitors. Diabetes Care. 2015 Sep;38(9):1638-42. doi: 10.2337/dc15-1380.

10. Filippi $C M$, von Herrath $M G$. Viral trigger for type 1 diabetes: pros and cons. Diabetes. 2008 Nov;57(11):2863-71. doi: 10.2337/db07-1023.

11. Li W, Moore MJ, Vasilieva N, et al. Angiotensin-converting enzyme 2 is a functional receptor for the SARS coronavirus. Nature. 2003 Nov 27;426(6965):450-4. doi: 10.1038/nature02145.

12. Hamming I, Timens $W$, Bulthuis ML, Lely AT, Navis $G$, van Goor H. Tissue distribution of ACE2 protein, the functional receptor for SARS coronavirus. A first step in understanding SARS pathogenesis. J Pathol. 2004 Jun;203(2):631-7. doi: 10.1002/ path. 1570 .

13. Harmer D, Gilbert M, Borman R, Clark KL. Quantitative $m R N A$ expression profiling of ACE 2, a novel homologue of angiotensin converting enzyme. FEBS Lett. 2002 Dec 4;532(1-2):107-10. doi: 10.1016/s0014-5793(02)03640-2.

14. Kreutz R, Algharably EAE, Azizi M, et al. Hypertension, the renin-angiotensin system, and the risk of lower respiratory tract infections and lung injury: implications for COVID-19. Cardiovasc Res. 2020 Aug 1;116(10):1688-1699. doi: 10.1093/cvr/cvaa097.

15. Graus-Nunes $F$, Souza-Mello $V$. The renin-angiotensin system as a target to solve the riddle of endocrine pancreas homeostasis. Biomed Pharmacother. 2019 Jan;109:639-645. doi: 10.1016/j. biopha.2018.10.191.

16. Bornstein SR, Dalan R, Hopkins D, Mingrone G, Boehm BO. Endocrine and metabolic link to coronavirus infection. Nat Rev Endocrinol. 2020 Jun;16(6):297-298. doi: 10.1038/s41574-0200353-9.

17. Roca-Ho H, Riera M, Palau V, Pascual J, Soler MJ. Characterization of ACE and ACE2 Expression within Different Organs of the NOD Mouse. Int J Mol Sci. 2017 Mar 5;18(3):563. doi: 10.3390/ijms 18030563.

18. Drucker DJ. Coronavirus Infections and Type 2 Diabetes-Shared Pathways with Therapeutic Implications. Endocr Rev. 
2020 Jun 1;41(3):bnaa011. doi: 10.1210/endrev/bnaa011.

19. Chee YJ, Ng SJH, Yeoh E. Diabetic ketoacidosis precipitated by Covid-19 in a patient with newly diagnosed diabetes mellitus. Diabetes Res Clin Pract. 2020 Jun;164:108166. doi: 10.1016/j. diabres.2020.108166.

20. Heaney AI, Griffin GD, Simon EL. Newly diagnosed diabetes and diabetic ketoacidosis precipitated by COVID-19 infection. Am J Emerg Med. 2020 Nov;38(11):2491.e3-2491.e4. doi: 10.1016/j.ajem.2020.05.114.

21. Palermo NE, Sadhu AR, McDonnell ME. Diabetic Ketoacidosis in COVID-19: Unique Concerns and Considerations. J Clin Endocrinol Metab. 2020 Aug 1;105(8):dgaa360. doi: 10.1210/clinem/dgaa 360

22. Wu C, Chen X, Cai Y, et al. Risk Factors Associated With
Acute Respiratory Distress Syndrome and Death in Patients With Coronavirus Disease 2019 Pneumonia in Wuhan, China. JAMA Intern Med. 2020 Jul 1;180(7):934-943. doi: 10.1001/jamainternmed.2020.0994.

23. Boddu SK, Aurangabadkar G, Kuchay MS. New onset diabetes, type 1 diabetes and COVID-19. Diabetes Metab Syndr. 2020 Nov-Dec;14(6):2211-2217. doi: 10.1016/j.dsx.2020.11.012.

\section{Information about authors}

Xhardo Elona, MD, PhD, Endocrinologist, Department of Internal Medicine; University Hospital "Shefqet Ndroqi", Tirana, Albania; e-mail: xhardo.elona@gmail.com; https://orcid.org/0000-0002-6811-5520 Kapisyzi Perlat, MD, Pulmonologist, Division of pulmonary diseases; Faculty of Medicine; University Hospital "Shefqet Ndroqi", Tirana, Albania; https://orcid.org/0000-0002-7296-404X Rada A., MD, Pulmonologist, Division of pulmonary diseases; Faculty of Medicine; University Hospital "Shefqet Ndroqi", Tirana, Albania

Conflicts of interests. Authors declare the absence of any conflicts of interests and their own financial interest that might be construed to influence the results or interpretation of their manuscript.

Xhardo E., Kapisyzi P., Rada A.

University Hospital "Shefqet Ndroqi", Tirana, Albania

Received 18.06.2021

Revised 14.07.2021

Accepted 02.08.2021

\section{Аіабетичний кетоациАоз, спричинений COVID-19, у пацієнта з уперше Аіагностованим цукровим Аіабетом}

Резюме. Актуальність. Коронавірусна хвороба 2019 р. (COVID-19) - це вірусне інфекційне захворювання, спричинене тяжким гострим респіраторним синдромом (SARS-CoV-2). Цукровий діабет (ЦД) часто діагностували в пацієнтів з новою коронавірусною хворобою - 2019, COVID-19. Це призводило до прогресуючого перебігу та гіршого прогнозу. Опубліковано небагато даних про діабетичний кетоацидоз (ДКА) при інфекції COVID-19. Повідомлялося про випадки зараження COVID-19, що спричинило вперше виявлений ЦД 2-го типу. Однак існує недостатня кількість доказів щодо ЦД 1-го типу. Автори наводять клінічний випадок ДКА, спричиненого COVID-19, у пацієнта з вперше виявленим ЦД 1-го типу. Нещодавно у звітах про клінічні випадки та невеликих перехресних дослідженнях описувалися пацієнти з ЦД, у яких розвивається ДКА при інфікуванні COVID-19. Встановлено, що частота ДКА $є$ високою в пацієнтів із ЦД як 1-го, так і 2-го типу, які були госпіталізовані з приводу COVID-19. Виклад випадку. Автори представили 29-річного, до настання COVID-19 здорового чоловіка з 5-денною історією лихоманки, втоми, блювання, полідипсії та поліурії. Його лабораторні результати продемонстрували високий рівень глюкози у крові, метаболічний ацидоз, кетонурію та ДКА. Крім того, у хворого був позитивний тест на COVID-19, і результати комп'ютерної томографії грудної клітки відповідали двобічній пневмонії COVID-19 (непрозорість, ущільнення легеневого рисунка). Його успішно лікували внутрішньовенним введенням рідини та інсуліном згідно з протоколом із ДКА. Хворий потребував внутрішньовенного введення антибіотиків, стероїдів та оксигенотерапії внаслідок пневмонії COVID-19. Через 14 днів він був виписаний у стабільному стані. Висновки. Інфекція COVID-19 може бути ускладнена ДКА та розвитком ЦД у осіб, які раніше не хворіли на цукровий діабет. Можливо, SARS-CoV-2 призводить до погіршення функції бета-клітин підшлункової залози та виникнення ДКА. У літературі повідомляється про незначну кількість випадків, коли інфекція COVID-19 викликала ДКА у хворого з нещодавно діагностованим цукровим діабетом 1-го типу.

Ключові слова: цукровий діабет 1-го типу; діабетичний кетоацидоз; пневмонія; COVID-19 